[Aus' dem Institut für Infectionskrankheiten zu Berlin.]

(Director: Geh. Med.-Rath Prof. Dr. R. Koch.)

\title{
Ueber ein biologisches Verfahren zur Differenzirung der Eiweissstoffe verschiedener Milcharten. Von
}

\author{
Dr. Albert Schütze.
}

Bei dem grossen allgemeinen Interesse und der hohen hygienischen Bedeutung, welche die Frage einer geeigneten Milchernährung, die nach dem Urtheile unserer berufenen Kliniker ein noch durchaus nicht gelöstes Problem darstellt, für sich in Anspruch nimmt, ist es nicht zu verwundern, dass namentlich in den letzten Jahren eine grosse Anzahl von sogenannten Milchpräparaten in den Handel gekommen sind, welche, soweit sie für die Säuglings-Ernährung bestimmt sind, zumeist so zusammengesetzt sein sollen, dass sie sich der Frauenmilch in ihrer Constitution nähern.

Alle diese Bestrebungen verfolgen das Ziel, die für die SäuglingsErnährung so wichtige "Muttermileh zu ersetzen.

Es ist daher eine Frage von grundlegender Bedeutung, ob es gelingt, einen näheren Einblick in die wichtigsten Nahrungsbestandtheile der Milch, nämlich die Eiweissstoffe, zu gewinnen. Wir haben nun in der jüngsten Zeit eine biologische Methode kennen gelernt, welche uns vielleicht gestattet, diesem Problem etwas näher zu treten, die es uns aber jedenfalls ermöglicht, zu bestimmen, ob die ron verschiedenen Thieren herrührenden Eiweissstoffe identisch sind oder nicht. Um diese Methode verständlich zu machen, müssen wir von einem Grundversuch Bordet' $\mathrm{s}^{1}$ ausgehen, welcher vor ea. 2 Jahren folgende Thatsache feststellte: Wenn man einem Thiere, z. B. einer Ziege, Rinderblut injicirt, so gewinnt nach einiger Zeit das Serum dieser Ziege die Eigenschaft, die rothen Blutkörperchen des Rindes zusammenzuballen und zur Auflösung zu bringen. Spritzen wir einer anderen Ziege Pferdeblut ein, so gewinnt nun diese Ziege die Eigenschaft, mit ihrem Serum die Blutkörperchen des Pferdes zusammenzuballen und aufzulösen. Nicht aber, vermag das erste Ziegenserum Pferdeblut zu lösen, oder umgekehrt das der zweiten Rinderblut. Also der Vorgang ist ein streng specifischer. Man hat nun dasselbe Experiment mit anderen

1 Annales de l'Institut Pasteur. 1898. T. XII et Avril 1899. 
Zellen wiederholt. So spritzte r. Dungern ${ }^{1}$ Meerschweinchen eine Emulsion von Flimmerepithelzellen ein und beobachtete dann in der That, dass das Serum der damit vorbehandelten Thiere nun diese zur Abtödtung bringt. Metschnikoff ${ }^{2}$, sowie der leider so früh verstorbene Moxter ${ }^{3}$ konnten zeigen, dass es durch Vorbehandlung von Thieren mit Hammelspermatozoën gelingt, ein Serum zu erhalten, das nur auf diese Samenzellen eine Wirkung ausübt. Kurz, durch Injectionen aller möglichen Zellenarten kann man bei Thieren ein Serum erzielen, das nur wieder die Zellen, mit welchen das Thier vorbehandelt war, in specifischer Weise beeinflusst.

Boten diese Resultate schon ein überraschendes Bild der ungeheuer vielseitigen Reactionsfähigkeit des lebenden thierisehen Organismus, so that dies ein anderes Experiment Bordet's ${ }^{4}$ in noch höherem Maasse. Dieser Autor konnte nämlich zeigen, dass nach wiederholten Injectionen von Kuhmilch bei dem hiermit vorbehandelten Thiere Stoffe im Blutserum auftreten, welche die Eiweisskörper der Kuhmilch ausfällen und zum Gerinnen bringen. Bordet deutete den Vorgang sofort sehr richtig als ein Analogon der specifischen Zusammenballung, Agglutination, wie wir diese nach der Vorbehandlung mit Blutkörperchen oder anderen Zellen durch das Serum der vorbehandelten Thiere auftreten sehen.

Diese ganz neuen und grundlegenden Versuche von Bordet veranlassten nun Hrn. Prof. A. Wassermann ${ }^{5}$, dem ich für sein dieser Arbeit entgegengebrachtes freundliches Interesse zu besonderem Danke verpflichtet bin, und mich, sie aus eigener Anschauung kennen zu lernen, und wir können in der That auf Grund der von uns gewonnenen Resultate die Angahen von Bordet voll und ganz bestätigen.

Wir gingen indess dann in unseren Versuchen weiter und legten uns die Frage vor, ob auch diese nach Injection von Mileh in dem Blutserum der also behandelten Thiere gebildeten, die Milch coagulirenden Stoffe specifisch sind, und wenn dies der Fall, ob es auf diese Weise gelingt, die Eiweisskörper verschiedener Milcharten zu unterscheiden, d. h. überhaupt unzweideutig festzustellen, ob dieselben von einander different sind. Dies ist uns in der That gelungen, und A. Wassermann hat bereits in der Discussion beim diesjährigen Congresse für innere Medicin in Wiesbaden Gelegenheit genommen, diese Methode zu empfehlen, um gewisse Eiweisskörper von einander zu unterscheiden. Inzwischen ist nun ein in diesem Jahre in der medicinischen Gesellschaft zu St. Louis in Amerika von

1 Münchener med. Wochenschrift. 1899. Nr. 38.

2 Annales de l'Institut Pasteur. Janvier 1900.

3 Deutsche med. Wochenschrift. 1900. Nr. 4.

4 Annales de l'Institut Pasteur. 1899. Nr. 3. p. 240 ff.

s Vgl. Deutsche med. Wochenschrift. Nr. 30. Vereinsbeilage, S. 178. 
C. Fisc $h^{1}$ gebaltener Vortrag in der jüngsten Zeit publicirt worden, aus welchem zu ersehen ist, dass $\mathrm{F}$ is $\mathrm{ch}^{2}$ gleichzeitig mit uns ganz ähnliche Experimente angestellt hat und $\mathrm{zu}$ den analogen Resultaten gelangt ist.

Der Vorgang bei unseren Versuchen war ein ganz einfacher: Wir nahmen mehrere Kaninchen und injicirten einem Theil der Thiere in Zwischenräumen von 3 bis 4 Tagen mehrmals subcutan 10 bis $20 \mathrm{~cm}$, in einigen Fällen sogar auf einmal 30 bis $50 \mathrm{~cm}$ roher mit Chloroform sterilisirter Kuhmilch, einem anderen Theil der Thiere die gleiche Menge ebenso behandelter Ziegen-, und einem dritten Frauenmilch, für deren gütige Ueberlassung wir der geburtshülflichen Abtheilung der Charité (Stabsarzt Green) zu grossem Danke verbunden sind. Nach ca. 3 Wochen dauernder Vorbehandlung wurde nun diesen Thieren, welche eine Gesammtmenge von etwa $100 \mathrm{~cm}$ erhalten hatten, Blut entzogen, und das Serum im Verhältniss von $1 / 2$ bis $1: 5$ zu verdünnter (ca. 1:40) Milch zugesetzt und einige Stunden bei Zimmertemperatur stehen gelassen. Da zeigte sich nun, dass das Serum der mit Kuhmilch vorbehandelten Kaninchen nur die Eiweisskörper der Kuhmilch ausfällt, nicht aber die der Frauen- oder Ziegenmilch, andererseits das Serum der mit Ziegenmilch vorbehandelten Thiere nur das Caseïn der Ziegenmilch u. s. w. Die zu häufigen Malen angestellten Versuche im Reagensglase haben den unzweideutigen Beweis erbracht, dass eine deutliche Ausfällung von Milch nur durch das Serum der mit der entsprechenden Milchart behandelten Thiere, auch nicht durch normales Kaninchenserum, welches stets zur Controle mit herangezogen war, zu Stande gebracht wird.

Wir haben also mittels des Bordet'schen Lactoserums eine durchaus exakt arbeitende, bequeme, biologische Methode gewonnen, welche gegenüber den bisher üblichen chemischen Verfahren grosse Vortheile bietet, um die Herkunft einer Milch zu bestimmen, und weiterhin ist ein ganz sicherer, einwandsfreier Beweis geliefert worden, dass die Eiweissmolecüle der verschiedenen Milcharten different sind. Es wird uns jetzt verständlicher, was wir empirisch schon wussten, wie verschieden gut von einzelnen Kranken die Milcharten verschiedener Thiere vertragen und ausgenützt werden.

Wir haben dann noch weitere Versuche angestellt, ob man mit Hülfe dieser neuen Methode vielleicht einen sicheren Anhaltspunkt für die Veränderung des Milcheiweisses beim intensiven Erhitzen erhält. Wenn man

${ }^{1}$ Studies on Lactoserum and on Other Cell-Sera. St. Louis Courier of Medic. Febr. 1900.

${ }^{2}$ Fisch hat nachgewiesen, dass man durch Einspritzung einer Emulsion von Euterzellen dieselben specifischen Stoffe im Serum erbält wie nach Injection von Milch. Es ist dies ein neuer Beweis dafür, dass die Milch nicht ein Filtrationsproduct ist, sondern eine wahre Zelllösung darstellt. 
Milch etwa eine halbe Stunde hindurch der Temperatur im Dampfkochtopf ilussetzt, so verliert diese Milch zum grössten Theil die Eigenschaft, auf ihr specifisches Lactoserum in der oben angegebenen Weise zu reagiren. Wir können also durch diesen Versuch nachweisen, dass beim intensiven Erhitzen eingreifende Veränderungen in dem Molecularbau der Eiweissstoffe vor sich gehen. Vielleicht ist uns durch diese Methode ein Weg gegeben, auf dem wir bei genauerer Ausarbeitung zu einer exacten Feststellung des Grades kommen können, bis zu welchem die Milch erhitzt werden darf, um bei genügender Sterilität eine geringste, $d . h$. eine eben wahrnehmbare Störung in ihren Eiweisskörpern zu erleiden.

Ueberblicken wir nunmehr das Ergebniss unserer Untersuchungen, so können wir daraus den wichtigen Schluss ziehen, dass jede Thierart ihre specifische Milch hat. Wir werden es daher, so lange wir die Eiweisskörper nicht willkürlich verändern können, als ein vergebliches Bemühen betrachten müssen, aus Kuhmilch ein Präparat herzustellen, welches der Frauenmilch in ihrer Zusammensetzung vollständig gleich kommt, obschon natürlich nicht geleugnet werden soll, dass in praxi die künstliche Säuglingsernährung unter günstigen Umständen vortreffliche Resultate liefern kann. Weiterhin werden wir unter den Ersatzpräparaten unbedingt denjenigen den Vorzug zu geben haben, bei welchen die Milch, bezw. deren Eiweisskörper, möglichst wenig verändert und in ihrem feineren Bau zerstört worden sind. Es befinden sich also die Ergebnisse dieser biologischen Methode, welche auf einer Prüfung der Milch mittels Lactoserums beruht, in voller Uebereinstimmung mit den Resultaten, wie sie die klinische Erfahrung festgestellt hat.

Wir haben hier mit Hülfe dieser biologischen Methode, welche präciser und schärfer, wie dies die chemische Analyse vermag ${ }^{1}$, uns von der Mannigfaltigkeit der Producte der menschlichen und thierischen Zellthätigkeit überzeugt, gesehen, wie specifisch die verschiedenen Milcheiweissarten sind, and wie der thierische Organismus auf die Injection von Frauenmilch mit einem ganz anderen Product als auf die Einverleibung von Kuhmilch u.s. w. antwortet. Es sind dies Resultate, welche uns indess nicht wunderbar erscheinen können, nachdem wir durch die jüngsten Untersuchungen von Ehrlich und Morgenroth über Auto- und Isolysine ${ }^{2}$ wissen, dass die Specifität der activen Substanzen im Organismus so,weit geht, dass sogar das einzelne Individuum Stoffe bildet, welche nur auf seine eigenen Zellen in charakteristischer Weise abgestimmt sind und die Zellen anderer Individuen derselben Art ganz anders beeinflussen.

${ }^{1}$ Anmerkung während der Correctur: Vgl. Uhlenhuth, Zum specifischen Nachweis von Eiereiweiss u. s. w. Deutsche med. Wochenschrift. 1900. Nr. 46.

2 Berliner klin. Wochenschrift. 1900. Nr. 21. 